\title{
NYUMPAH: UNGKAPAN KEMARAHAN DALAM MASYARAKAT MELAYU PONTIANAK KALIMANTAN BARAT
}

\section{NYUMPAH: ANGER EXPRESSION IN THE SOCIETY OF PONTIANAK MALAY KALIMANTAN BARAT}

\author{
Syarifah Lubna \\ Balai Bahasa Kalimantan Barat \\ lubna_alkadrie@yahoo.com
}

\begin{abstract}
ABSTRAK
Sebagaimana keunikan yang dimiliki masing-masing bahasa, ungkapan kemarahan juga merupakan sesuatu yang khas dan unik yang diekspresikan berlainan bergantung budaya masyarakat masing-masing, termasuk masyarakat Melayu Pontianak, Kalimantan Barat. Berkaitan dengan kekhasan ini, sejak kecil atau sekarang masyarakat Melayu Pontianak Kalimantan Barat tidak hanya mengungkapkan kemarahannya akibat ketidaksetujuan akan suatu hal atau selisih pendapat dan paham, namun lebih dari itu ungkapan kemarahan juga menunjukkan rasa peduli dan kedekatan dalam lingkungan terdekat. Terdapat berbagai ungkapan kemarahan masyarakat Melayu Pontianak Kalimantan Barat, termasuk nyumpah. Nyumpah menjadi fokus penelitian untuk dideskripsikan secara kualitatif dan menjadi tujuan penelitian ini. Sampel penelitian yaitu 100 responden dipilih secara acak dari total populasi masyarakat Melayu Pontianak Kalimantan Barat. Penelitian ini menggunakan statistika deskriptif. Data dikumpulkan melalui angket atau kuesioner dan dianalisis melalui tabulasi statistical product and service solution (SPSS) berdasarkan skala likert yaitu: sangat tidak setuju (1), tidak setuju (2), ragu-ragu (3), setuju (4), dan sangat setuju (5). Berdasarkan data tersebut dapat disimpulkan bahwa masyarakat Melayu Pontianak tidak lagi mengungkapkan kemarahannya dalam bentuk nyumpah dalam lingkungan pergaulan terdekat dan keluarga (66\% responden tidak setuju bahkan sangat tidak setuju).

Kata kunci: ungkapan kemarahan, Melayu Pontianak, Kalimantan Barat, nyumpah
\end{abstract}

\begin{abstract}
As the uniqueness of each language, the expression of anger is also something unique and peculiar which is expressed differently depending on the culture of each community, including the society of Pontianak Malay Kalimantan Barat. In connection with this peculiarity, since childhood or nowadays the society of Pontianak Malay Kalimantan Barat do not only reflect dislike, disapproval of things and differences of opinion or understanding through anger, but more than that the expressions of anger also shows caring and closeness in the closest environment such as family and daily interactions. There are various expressions of anger in the society of Pontianak Malay Kalimantan Barat including nyumpah.
\end{abstract}


Tuah Talino

Tahun XIII Volume 13 Nomor 2 Edisi 6 Desember 2019

ISSN 0216-079X E-ISSN 2685-3043

Balai Bahasa Kalimantan Barat

Nyumpah is the focus and aim of the research to be described qualitatively. The research sample was 100 respondents selected randomly from the total population of the society of Pontianak Malay Kalimantan Barat. This study applied descriptive statistics. The data collected and disseminated through questionnaires and analyzed through tabulation of statistical product and service solution (SPSS) based on the Likert scale which are: strongly disagree (1), disagree (2), doubtful (3), agree (4), and strongly agree (5). Based on the data, it could be concluded that society of Pontianak Malay not expressing their anger through nyumpah in the closest social environment and family (66\% of respondents not agree and even strongly not agree).

Keywords: anger expressions, Pontianak Malay, Kalimantan Barat, nyumpah.

\section{PENDAHULUAN}

Bahasa sering dihubungkan dengan emosi. Wierzbicka mengutarakan bahwa "setiap bahasa memaksakan klasifikasi sendiri atas pengalaman emosional manusia, dan kata-kata bahasa Inggris seperti kemarahan atau kesedihan adalah artefak budaya dari bahasa Inggris, bukan budaya bebas" (1992: 456). Ketidakbebasan ini tampak pula pada setiap bahasa lain. Sejak kecil kita telah berkomunikasi dengan bahasa ibu untuk menyampaikan semua pikiran, perasaan dan keinginan termasuk mengeskpresikan kemarahan. William (1998: 36-44) menyatakan bahwa "when using the second or foreign language, the emotional component often gets lost; as a matter of course, writers (or speakers) feel more detached and relate to the language as a tool rather than as a means of cultural identification". Artinya ketika kita menggunakan bahasa kedua atau asing, komponen emosional sering hilang; penulis (atau penutur) biasanya secara terpisah telah menggunakan dan berhubungan dengan bahasa sebagai alat, bukan sebagai sarana identifikasi budaya. Berdasarkan alasan inilah, bahasa ibu lebih sering digunakan untuk mengekspresikan perasaan terutama dalam keluarga dan lingkungan terdekat.

Berbagai macam perasaan dapat diekspresikan atau diungkapkan dalam keluarga dan lingkungan terdekat. Perasaan itu bisa berupa: kecintaan, kepedulian, keakraban, sayang, bahkan kemarahan. Kemarahan adalah emosi yang tampaknya akan menjadi universal dan tidak dipelajari seperti emosi yang lain, namun berbeda manifestasinya dalam berbagai budaya (Solomon dalam Shweder and LeVine; 1984:242). Ada banyak kegiatan dan aktivitas sehari-hari yang dapat menimbulkan kemarahan, misalnya ketidaksetujuan akan suatu hal, selisih pendapat atau paham, baik dalam dirinya, maupun dari lingkungan sekitarnya. Selanjutnya, ungkapan kemarahan yang ditunjukkan pada keluarga dan lingkungan terdekat ini dapat diungkapkan secara verbal dan nonverbal termasuk nyumpah. Lubna (2016) menyebutkan bahwa nyumpah adalah ungkapan kemarahan yang menyebutkan kata-kata sumpah sebagai wujud tidak suka pada seseorang. Selain itu nyumpah juga dapat menunjukkan kedekatan dengan seseorang dengan cara saling menjelek-jelekkan untuk menunjukkan keakraban. Kedua sahabat yang lama tak berjumpa juga dapat menyebut atau memanggil temannya dengan panggilan yang menurut orang lain kasar sebagai tanda kedekatan dan keakraban hubungan mereka. Nyumpah juga menggunakan kata- 
Tuah Talino

Tahun XIII Volume 13 Nomor 2 Edisi 6 Desember 2019

ISSN 0216-079X E-ISSN 2685-3043

Balai Bahasa Kalimantan Barat

kata makian dalam bahasa Melayu dan seputar budaya Melayu Pontianak Kalimantan Barat. Ungkapan kemarahan yang ditunjukkan dalam kata puake, jin betendang, jin epret, jahannam, antu kopek, ebles, setan, celake dan sebagainya sebenarnya juga mewakili kekhasan budaya Melayu Pontianak Kalimantan Barat yang tidak dimiliki oleh wilayah lain di Indonesia.

Ungkapan kemarahan secara verbal ini kadang juga dilengkapi dengan ekspresi yang bersifat non verbal, misalnya mata melotot, wajah memerah, bibir mencibir atau agak monyong, nada suara meninggi, bahkan diam. Itu sebabnya, keberagaman ungkapan kemarahan ini termasuk suatu kajian dan studi yang menarik untuk diteliti. Namun, penelitian terdahulu secara khusus terkait dalam hal ini belum peneliti temukan. Lubna (2016) telah mendeskripsikan tentang ekspresi kemarahan dalam bahasa Melayu Pontianak Kalimantan Barat. Ia mendeskripsikan tentang beleter, ngambol, nyumpah, nyeranah, dan pendek tongkeng. Sebelumnya, Lubna (2011a) juga telah menulis tentang bagaimana ternyata beleter sebagai salah satu sikap marah dapat menjadi upaya pemertahanan budaya Melayu melalui ekspresi-ekspresi kemarahan yang diungkapkannya. Nilai-nilai budaya ini selain mewariskan kearifan lokal dari orang Melayu berusia tua ke orang Melayu berusia muda, juga sekaligus memertahankan bahasa Melayu itu sendiri untuk dapat terus eksis di Pontianak, Kalimantan Barat (Lubna, 2011b).

Hasil penelitian di atas dapat menjadi rujukan pengetahuan tentang sikap marah atau ungkapan kemarahan masyarakat Melayu Pontianak Kalimantan Barat. Kedua tulisan bersifat kualitatif yang mendeskripsikan bagaimana cara marah atau sikap marah yang berlaku pada masyarakat Melayu. Tulisan tersebut juga berpumpun pada pengetahuan dan pengalaman penulisnya yang juga berperan sebagai penutur asli bahasa Melayu Pontianak.

Secara lebih khusus, belum ada penelitian yang mengulas mengenai ungkapan kemarahan dalam bentuk nyumpah pada masyarakat Melayu Pontianak Kalimantan Barat karena penelitian sebelumnya baru membahas tentang pengenalan umum ekspresi kemarahan ini dan ekspresi kemarahan dalam bentuk beleter. Padahal, data kualitatif dalam bentuk angka dan persentase diperlukan untuk mendeskripsikan dan memberikan gambaran umum bagaimana masyarakat Melayu Pontianak mengungkapkan kemarahannya dalam keseharian masyarakat Melayu Pontianak. Ungkapan kemarahan khususnya dalam bentuk nyumpah perlu kita petakan setidaknya dalam bentuk umum sehingga kita dapat melihat bagaimana ungkapan kemarahan masyarakat Melayu Pontianak Kalimantan Barat khususnya dalam bentuk nyumpah ini.

Jadi, untuk melengkapi rumpang data penelitian tersebut, peneliti mendeskripsikan ungkapan kemarahan masyarakat Melayu Pontianak, Kalimantan Barat khususnya nyumpah dalam bentuk deskriptif statistik. Hal ini perlu diteliti sebagai upaya pemetaan bagaimana ungkapan kemarahan dalam bahasa yang merupakan akar bahasa Indonesia ini. Pemaparan mengenai ungkapan kemarahan secara persentase angka diharapkan juga dapat menjadi rujukan awal dalam pemetaan sikap bahasa masyarakat Melayu Pontianak Kalimantan Barat pula secara umum. Cara marah atau ungkapan kemarahan inilah yang diulas sehingga menjadi masalah penelitian yang akan dijawab dalam tujuan penelitian. Jawaban 
Tuah Talino

Tahun XIII Volume 13 Nomor 2 Edisi 6 Desember 2019

ISSN 0216-079X E-ISSN 2685-3043

Balai Bahasa Kalimantan Barat

pertanyaan "Bagaimana ungkapan kemarahan masyarakat Melayu Pontianak Kalimantan Barat dalam bentuk nyumpah?" diharapkan dapat memberikan masukan pengetahuan dalam pengembangan linguistik khususnya sosiolinguistik tentang simpulan mengenai ungkapan kemarahan masyarakat Melayu Pontianak Kalimantan Barat dalam bentuk nyumpah.

Selain itu, pemerolehan data kualitatif dalam bentuk angka dan grafis mengenai ungkapan kemarahan khususnya dalam bentuk nyumpah dalam masyarakat Melayu Pontianak Kalimantan Barat dapat menjadi acuan untuk penelitian sejenis dengan ranah lain yang lebih khusus. Secara praktis penelitian ini diharapkan juga dapat memberikan gambaran atau pendeskripsian tentang ungkapan kemarahan masyarakat Melayu Pontianak Kalimantan Barat khususnya dalam bentuk nyumpah. Pendeskripsian yang baik diharapkan menjadi muara yang baik dalam memahami tentang ungkapan kemarahan dalam masyarakat Melayu Pontianak Kalimantan Barat sehingga menjadi upaya dalam meminimalisasi munculnya konflik dalam masyarakat akibatnya kurangnya pemahaman terhadap masyarakat Melayu Pontianak Kalimantan Barat. Kepahaman yang baik juga dapat menciptakan pemahaman silang budaya dan harmonisasi yang baik dalam hubungan masyarakat multi etnis yang lazim terjadi di Indonesia termasuk di Pontianak Kalimantan Barat.

\section{METODE}

Penelitian ini menerapkan penafsiran deskriptif dalam bentuk statistika deskriptif yaitu cabang statistika yang berkaitan dengan prosedur-prosedur yang digunakan untuk menjelaskan karakteristik data secara umum (Kusnandar, dkk, 2019: 10). Statistika data yang digunakan untuk mengelompokkan, menyederhanakan, dan menyajikan data ke dalam bentuk yang mudah dimengerti. Hal ini memungkinkan pengguna data untuk dapat memahami data dan menggali lebih banyak informasi tentang karakteristik data, yang biasanya tidak terlihat dalam tampilan data mentahnya.

Berikutnya, penelitian menerapkan metode survei untuk mengambil sampel dari populasi dan mengumpulkan data melalui kuesioner sebagai alat pengumpul data yang pokok. Penerapan metode ini bertujuan untuk menggambarkan dan menafsirkan hal yang berkenaan dengan suatu kondisi atau gejala seperti apa adanya atau mendeskripsikan gejala faktual dan kaitan berbagai variabel masalah yang diteliti secara sistematis.

\section{Sumber Data dan Data}

Sumber data adalah populasi masyarakat penutur bahasa Melayu Pontianak, baik laki-laki maupun perempuan. Mahsun (2005:210) berpendapat bahwa dalam penelitian bahasa, sampel yang besar tidak diperlukan karena perilaku linguistik cenderung lebih homogen dibandingkan perilaku-perilaku lainnya. Ahsen (dalam Mahsun, 2005:210) juga menyebutkan bahwa penelitian sosiolinguistik yang hasilnya telah diterbitkan ternyata menggunakan sampel dalam jumlah yang tidak besar. Berdasarkan pada dua pendapat itu, sampel atau data yang digunakan dalam penelitian ini berjumlah 100 (seratus) orang dari sumber data atau populasi yang mewakili masyarakat Melayu Pontianak Kalimantan Barat. 
Tuah Talino

Tahun XIII Volume 13 Nomor 2 Edisi 6 Desember 2019

ISSN 0216-079X E-ISSN 2685-3043

Balai Bahasa Kalimantan Barat

Penentuan data penelitian dilakukan secara acak (random sample) sesuai dengan penjelasan Kusnandar, dkk (2019:93) sehingga anggota populasi mempunyai kesempatan yang sama untuk terpilih sebagai anggota sampel. Penentuan data dilakukan dengan menyebar tautan kuesioner dalam waktu tiga hari melalui kelompok-kelompok percakapan dalam media sosial what's up yang mempunyai basis anggota penutur bahasa Melayu Pontianak.

Setiap penutur yang mengklik tautan kuesioner yang terhubung dengan google form ini dapat mengisi kuesioner berdasarkan pada pemahaman dan pendapatnya masing-masing melalui ponsel pintarnya. Penjaringan responden ini dapat mengumpulkan 161 orang yang bersedia mengisi kuesioner dan dipilihlah seratus responden yang mengisi kuesioner penelitian bahasa.

Masyarakat Melayu yang mengisi kuesioner namun sudah tidak berdomisili di kota Pontianak tidak dipilih atau dieliminasi menjadi responden. Selain itu masyarakat yang tidak menjadikan bahasa Melayu Pontianak sebagai bahasa pertama juga tidak dipilih. Ada juga responden yang menyebutkan bahasa Indonesia sebagai bahasa pertamanya dan bahasa Melayu sebagai bahasa keduanya. Mereka yang mengisi seperti ini tetap dipilih menjadi responden karena berdomisili di Pontianak dan menguasai dengan baik bahasa Melayu Pontianak.

Penguasaan bahasa Melayu ini ditunjukkan dengan pemahaman terhadap bahasa Melayu yang baik. Pemahaman yang baik dibuktikan oleh jumlah jawaban yang benar pada pertanyaan yang diberikan oleh peneliti dalam kuesioner sebagai langkah awal pencocokan atau penyamaan persepsi mengenai berbagai ungkapan kemarahan yang berlaku dalam masyarakat Melayu Pontianak.

Ungkapan kemarahan ini juga menjadi variabel utama penelitian ungkapan kemarahan dalam masyarakat Melayu Pontianak Kalimantan Barat ini. Selanjutnya, variabel pengamatan yaitu ungkapan kemarahan dalam bentuk nyumpah.

\section{Profil Data}

Data atau sampel penelitian atau selanjutkan akan disebut sebagai responden adalah masyarakat yang menuturkan bahasa Melayu Pontianak. Responden penelitian terdiri atas laki-laki yang berjumlah 28 orang dan perempuan yang berjumlah 72 orang. Responden penelitian terdiri atas 5 orang yang berusia kurang atau sama dengan 17 tahun, 31 orang berusia 18-25 tahun, 26 orang berusia 26 sampai dengan 35 tahun. Responden dengan rentang usia 36-45 tahun berjumlah 31 orang, responden dengan rentang usia 46 sampai dengan 55 tahun berjumlah 4 orang, dan responden dengan rentang usia 56-65 tahun berjumlah 1 orang. Yang terakhir, responden dengan rentang usia diatas 65 tahun berjumlah 2 orang.

Pendidikan tertinggi responden penelitian adalah tamatan SMP 2 orang, SMA 35 orang, strata 1 sejumlah 52 orang, dan strata 2 berjumlah 11 orang. Pekerjaan responden penelitian adalah rumah tangga berjumlah 13 orang, PNS berjumlah 16 orang, TNI/Polri berjumlah 6 orang. Responden yang bekerja pada sektor swasta berjumlah 30 orang dan wiraswasta berjumlah 5 orang. Terdapat honorer berjumlah 1 orang, pegawai BUMN 1 orang, pelajar berjumlah 6 orang, mahasiswa 14 orang, tenaga pendidik berjumlah 5 orang, dokter intern 1 orang dan responden yang belum bekerja berjumlah 1 orang. 
Tuah Talino

Tahun XIII Volume 13 Nomor 2 Edisi 6 Desember 2019

ISSN 0216-079X E-ISSN 2685-3043

Balai Bahasa Kalimantan Barat

17 orang responden tinggal di kawasan Pontianak Timur, 19 orang di kawasan Pontianak Barat, 33 orang di kawasan Pontianak Kota, 10 orang di kawasan Pontianak Tenggara, 17 orang di kawasan Pontianak Selatan dan 4 orang di kawasan Pontianak Utara.

Data yang digunakan adalah data yang diperoleh melalui penyebaran angket atau kuesioner yang berpedoman pada Skala Likert untuk mengetahui ungkapan kemarahan dalam bentuk nyumpah. Data yang diperoleh adalah data kualitatif, yaitu data yang berupa angka-angka dari hasil pengukuran yang berupa pertanyaan atau pernyataan yang terkait dengan ungkapan kemarahan dalam bentuk nyumpah pada masyarakat Melayu Pontianak, Kalimantan Barat.

Data yang telah terkumpul selanjutnya diolah dengan langkah-langkah sebagai berikut.

(1) Membuat tabulasi skor kuesioner ungkapan kemarahan masyarakat Melayu Pontianak Kalimantan Barat.

(2) Deskripsi infografis dalam bentuk tabel dan grafik dengan menggunakan SPSS dan Microsoft Excell.

(3) Deskripsi infografis dalam bentuk kalimat.

Kuesioner yang didistribusikan terdiri atas (1) profil responden dengan 8 pertanyaan tertutup dan (2) pertanyaan mengenai berbagai ungkapan kemarahan dalam masyarakat Melayu Pontianak Kalimantan Barat (3) pernyataan yang terkait dengan ungkapan kemarahan nyumpah.

Responden diharapkan menjawab dengan jawaban sangat tidak setuju, tidak setuju, ragu-ragu, setuju, dan sangat setuju. Terdapat lima pernyataan yang merupakan penjabaran dari ungkapan kemarahan dalam bentuk nyumpah. Responden diberikan kesempatan untuk menjawab salah satu dari lima buah opsi pilihan jawaban dengan bobot skala 5,4,3,2, dan 1 .

\section{Validitas dan Reliabilitas}

Teknik pengolahan data dalam penelitian ini menggunakan penghitungan komputasi program SPSS (Statistical Product and Service Solution) karena program ini memiliki kemampuan analisis statistik cukup tinggi serta sistem manajemen data pada lingkungan grafis menggunakan menu-menu deskriptif dan kotak-kotak dialog sederhana, sehingga mudah dipahami cara pengoperasiannya (Sugianto, 2007: 1).

Uji validitas dan reliabilitas item kuesioner dalam penelitian ini menggunakan SPSS. Berdasarkan uji validitas dalam SPSS semua item valid untuk dijadikan instrumen pengumpulan data. Sedangkan berdasarkan uji reliabilitas dengan tehnik split half menggunakan SPSS semua kuesioner dalam penelitian Ungkapan Kemarahan Masyarakat Melayu Pontianak Kalimantan Barat ini juga tergolong reliabel.

\section{Teknik Analisis Data}

Data tersebut dianalisis secara statistika deskriptif. Analisis dilakukan berdasarkan jawaban-jawaban atas pertanyaan yang dilakukan dan diberi bobot berdasarkan skala Likert. Materi kuesioner terdiri atas profil responden, pertanyaan dan pernyataan mengenai hal-hal yang terkait dengan ungkapan kemarahan dalam masyarakat Melayu Pontianak, Kalimantan Barat. 
Tuah Talino

Tahun XIII Volume 13 Nomor 2 Edisi 6 Desember 2019

ISSN 0216-079X E-ISSN 2685-3043

Balai Bahasa Kalimantan Barat

Statistika deskriptif dilakukan karena setiap set data hampir dapat dipastikan mempunyai keragaman atau variasi, tidak semuanya bernilai sama atau dengan kata lain terdapat nilai pengamatan yang berbeda dengan nilai pengamatan lainnya. Akan tetapi, keragaman nilai-nilai pengamatan tersebut seringkali mengikuti suatu pola atau bentuk tertentu yang khas, yang merupakan ciri atau karakteristik data.

Kusnandar (2019:10) juga mengatakan bahwa statistik deskriptif digunakan untuk mengelompokkan, menyederhanakan, dan menyajikan data ke dalam bentuk yang mudah dimengerti. Pada penelitian ini, metode statistika deskriptif yang digunakan adalah tabel dan grafik atau diagram.

Penyajian data dalam bentuk grafik atau diagram bertujuan untuk memvisualisasikan data secara keseluruhan dengan menonjolkan karakteristik tertentu dari data tersebut. Diagram yg digunakan dalam penelitian ini adalah diagram dalam bentuk lingkaran dan batang.

Penyajian data ini menggunakan bantuan aplikasi SPPS (Statistics Package for Social Scientist) dan Microsoft Excell. Data yang ada diolah dan diproses untk disajikan kembali dengan menggunakan statistik deskriptif dan kros-tabulasi (crosstabulation). Statistik deskriptif ini akan dideskripsikan juga dalam bentuk kalimat untuk menjawab masalah penelitian yang telah dirumuskan.

\section{HASIL DAN PEMBAHASAN}

Ungkapan kemarahan yang akan dideskripsikan adalah ungkapan kemarahan dalam bentuk nyumpah. Terdapat lima pernyataan berkaitan dengan ungkapan kemarahan ini.

Pernyataan pertama yaitu Saya menyumpah/memaki untuk menunjukkan rasa marah saya pada orang yang dekat dengan saya. Reaksi responden terhadap pernyataan ini tampak diagram di bawah ini.

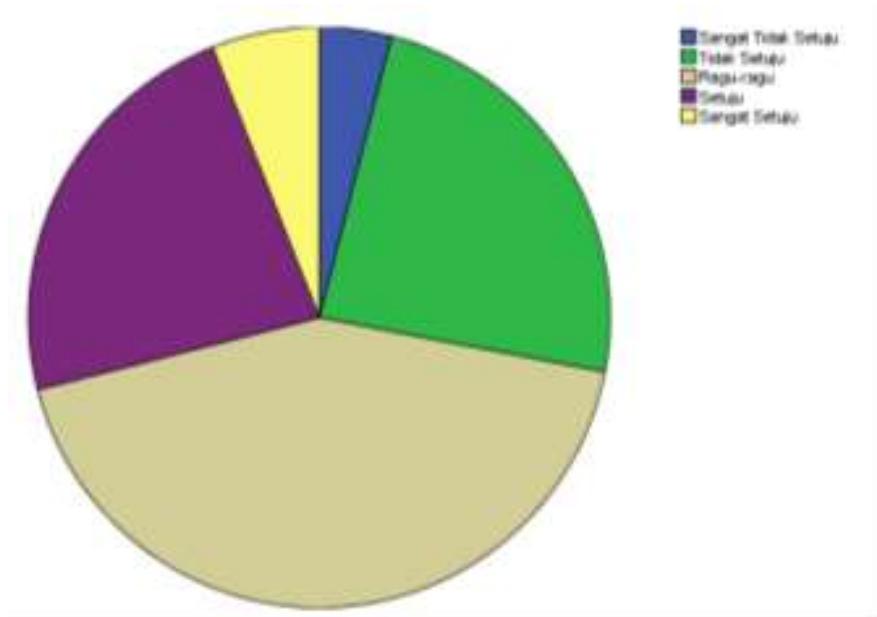

Gambar 1. Saya menyumpah/ memaki untuk menunjukkan rasa marah saya pada orang yang dekat dengan saya

Berdasarkan tanggapan di atas, terlihat dan terbaca bahwa 4 responden sangat tidak setuju, 24 responden tidak setuju, dan 43 responden merasa ragu untuk menyatakan bahwa mereka menyumpah/memaki untuk menunjukkan rasa 
marah mereka pada orang yang dekat dengan mereka. Sedangkan 23 responden setuju dan 6 responden sangat setuju menyatakan bahwa mereka menyumpah/ memaki untuk menunjukkan rasa marah mereka pada orang yang dekat dengan mereka.

Secara persentase ini berarti bahwa 4 persen responden sangat tidak setuju, 24 persen responden tidak setuju, dan 43 persen responden merasa ragu untuk menyatakan bahwa mereka menyumpah/memaki untuk menunjukkan rasa marah mereka pada orang yang dekat dengan mereka. Sedangkan 23 persen responden setuju dan 6 persen responden sangat setuju menyatakan bahwa mereka menyumpah/memaki untuk menunjukkan rasa marah mereka pada orang yang dekat dengan mereka.

Pernyataan kedua yaitu saya menyumpah untuk menunjukkan rasa marah saya pada orang yang tidak dekat dengan saya. Reaksi responden terhadap pernyataan ini tampak pada gambar di bawah ini.

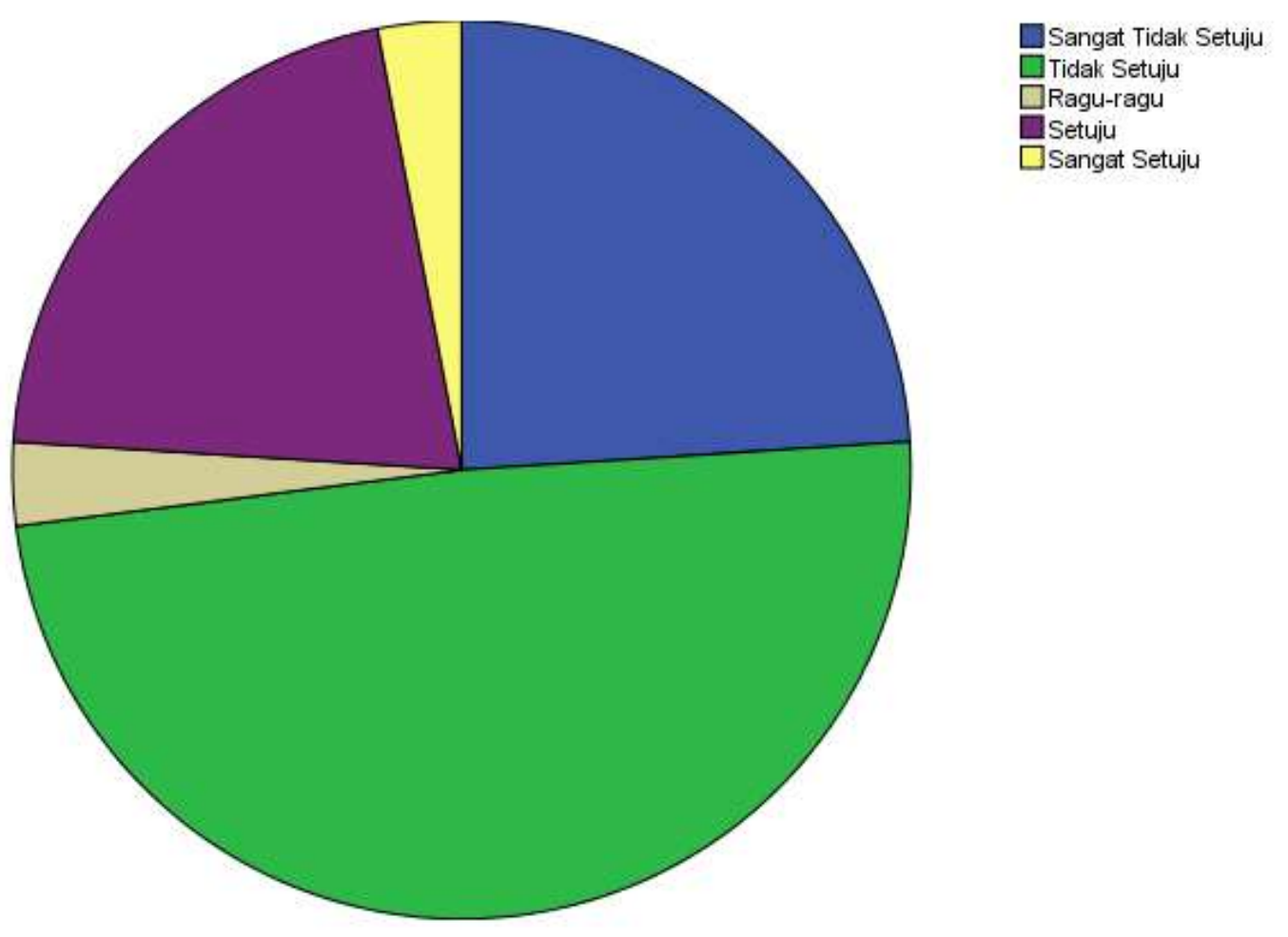

Gambar 2. Saya menyumpah untuk menunjukkan rasa marah saya pada orang yang tidak dekat dengan saya

Berdasarkan tanggapan di atas, terlihat dan terbaca bahwa 24 responden sangat tidak setuju, 49 responden tidak setuju, dan 3 responden merasa ragu untuk menyatakan bahwa mereka menyumpah/memaki untuk menunjukkan rasa marah mereka pada orang yang tidak dekat dengan mereka. Sedangkan 21 responden setuju dan 3 responden sangat setuju menyatakan bahwa mereka menyumpah/ 
memaki untuk menunjukkan rasa marah mereka pada orang yang tidak dekat dengan mereka.

Secara persentase ini berarti bahwa 24 persen responden sangat tidak setuju, 49 persen responden tidak setuju, dan 3 persen responden merasa ragu untuk menyatakan bahwa mereka menyumpah/memaki untuk menunjukkan rasa marah mereka pada orang yang tidak dekat dengan mereka. Sedangkan 21 persen responden setuju dan 3 persen responden sangat setuju menyatakan bahwa mereka menyumpah/memaki untuk menunjukkan rasa marah mereka pada orang yang tidak dekat dengan mereka.

Pernyataan ketiga yaitu saya menyumpah untuk menunjukkan kedekatan saya dengan orang lain. Reaksi responden terhadap pernyataan ini tampak pada tabel dan diagram di bawah ini.

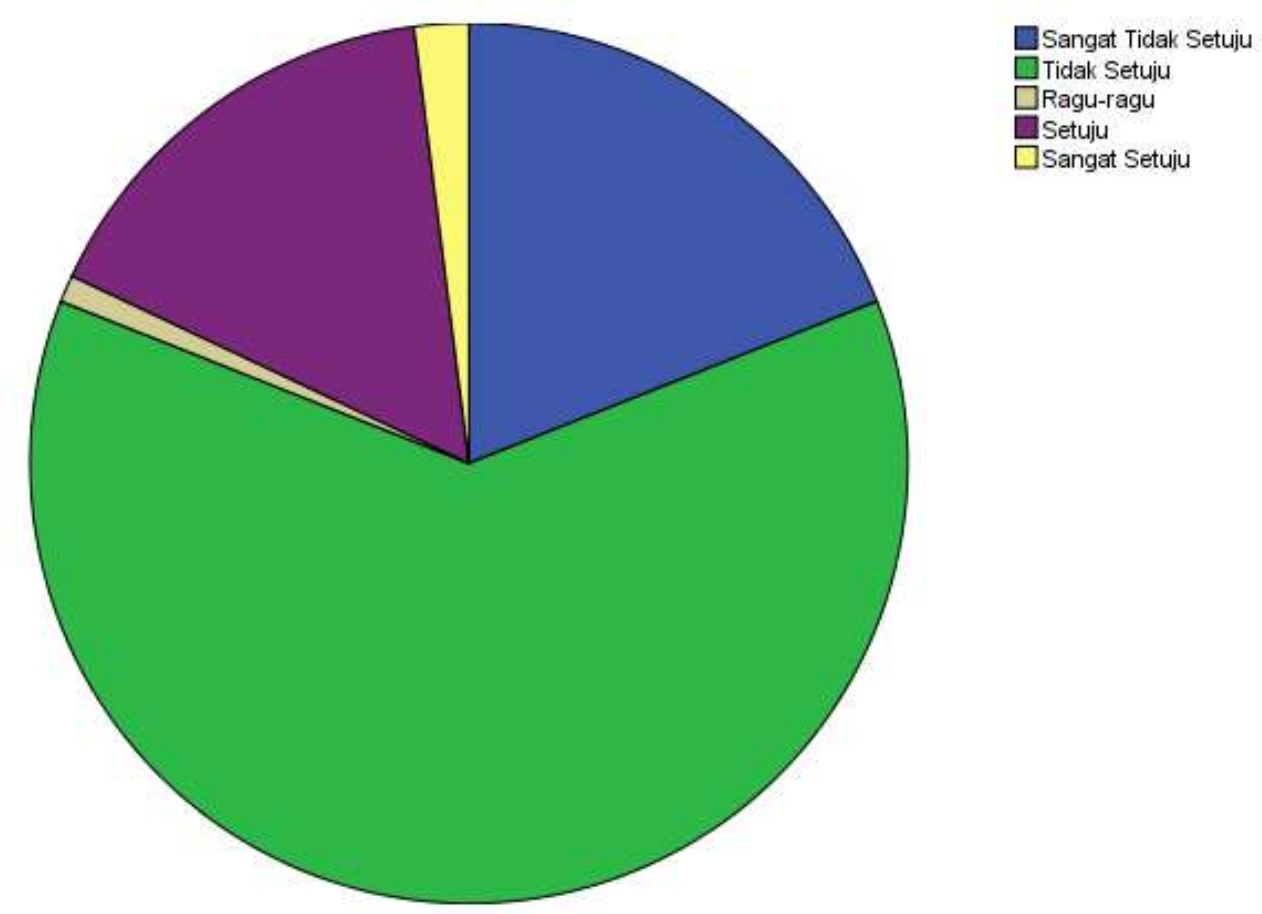

Gambar 3. Saya menyumpah untuk menunjukkan kedekatan saya dengan orang lain

Kedekatan pada seseorang kadang menyebabkan hilangnya sekat batas dalam berbahasa karena keakraban yang terbina. Hal ini kadang menyebabkan seseorang bebas mengutarakan apa yang diinginkan atau dipikirkannya dalam lingkungan terdekatnya termasuk kadang kata-kata makian yang cenderung kasar. Namun, berdasarkan tanggapan di atas, terlihat dan terbaca bahwa 19 responden sangat tidak setuju, 62 responden tidak setuju, dan 1 responden merasa ragu untuk menyatakan bahwa mereka menyumpah untuk menunjukkan kedekatan mereka dengan orang lain. Sedangkan 16 responden setuju dan 2 responden sangat setuju menyatakan bahwa mereka menyumpah untuk menunjukkan kedekatan mereka dengan orang lain. 
Secara persentase ini berarti bahwa 19 persen responden sangat tidak setuju, 62 persen responden tidak setuju, dan 1 persen responden merasa ragu untuk menyatakan bahwa mereka menyumpah untuk menunjukkan kedekatan mereka dengan orang lain. Sedangkan 16 persen responden setuju dan 2 persen responden sangat setuju menyatakan bahwa mereka menyumpah untuk menunjukkan kedekatan mereka dengan orang lain.

Pernyataan keempat yaitu saya menyumpah untuk menunjukkan kepedulian dan kasih sayang saya terhadap orang lain. Reaksi responden terhadap pernyataan ini tampak pada diagram di bawah ini.

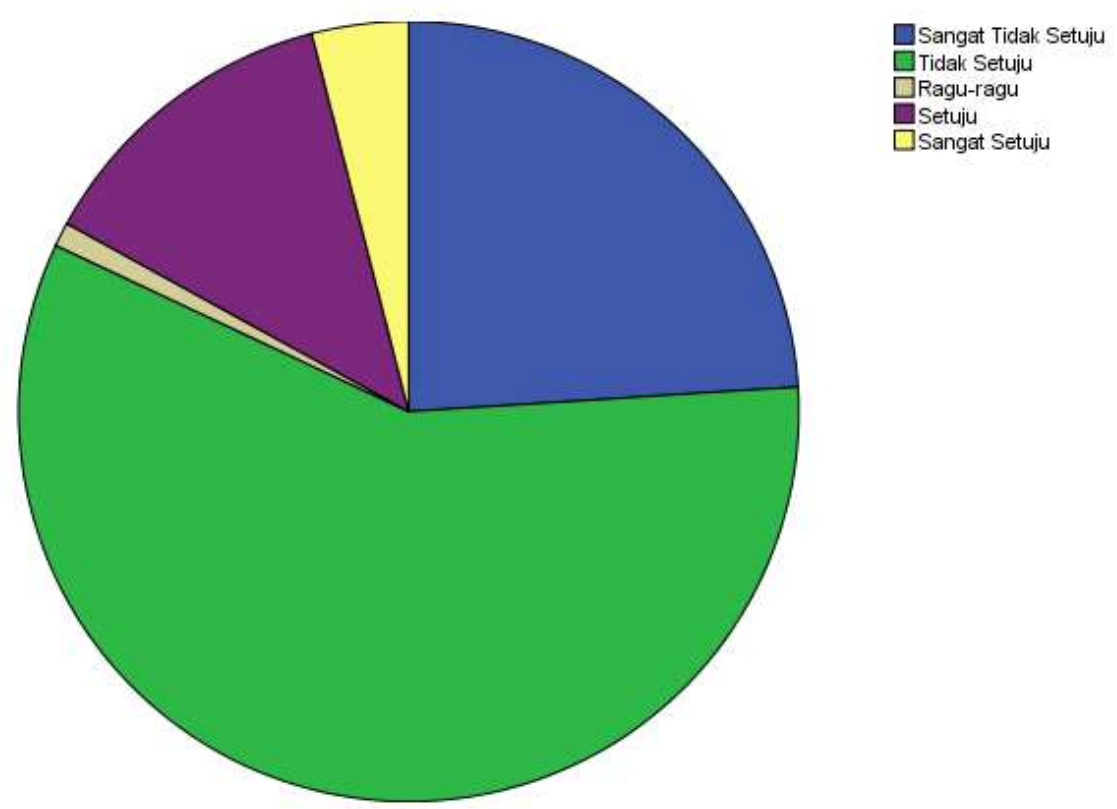

Gambar 4. Saya menyumpah untuk menunjukkan kepedulian dan kasih sayang saya terhadap orang lain

Berdasarkan tanggapan di atas, terlihat dan terbaca bahwa 24 responden sangat tidak setuju, 58 responden tidak setuju, dan 1 responden merasa ragu untuk menyatakan bahwa mereka menyumpah untuk menunjukkan kepedulian dan kasih sayang mereka terhadap orang lain. Sedangkan 13 responden setuju dan 4 responden sangat setuju menyatakan bahwa mereka menyumpah untuk kepedulian dan kasih sayang mereka terhadap orang lain.

Secara persentase ini berarti bahwa 24 persen responden sangat tidak setuju, 58 persen responden tidak setuju, dan 1 persen responden merasa ragu untuk menyatakan bahwa mereka menyumpah untuk menunjukkan kepedulian dan kasih sayang mereka terhadap orang lain. Sedangkan 13 persen responden setuju dan 4 persen responden sangat setuju menyatakan bahwa mereka menyumpah untuk menunjukkan kepedulian dan kasih sayang mereka terhadap orang lain. 
Tuah Talino

Tahun XIII Volume 13 Nomor 2 Edisi 6 Desember 2019

ISSN 0216-079X E-ISSN 2685-3043

Balai Bahasa Kalimantan Barat

Pernyataan kelima yaitu saya menyumpah dengan menyebutkan kata makian misalnya jahannam, antu kopek, jin betendang, puake, dan sebagainya. Reaksi responden terhadap pernyataan ini tampak pada gambar di bawah ini.

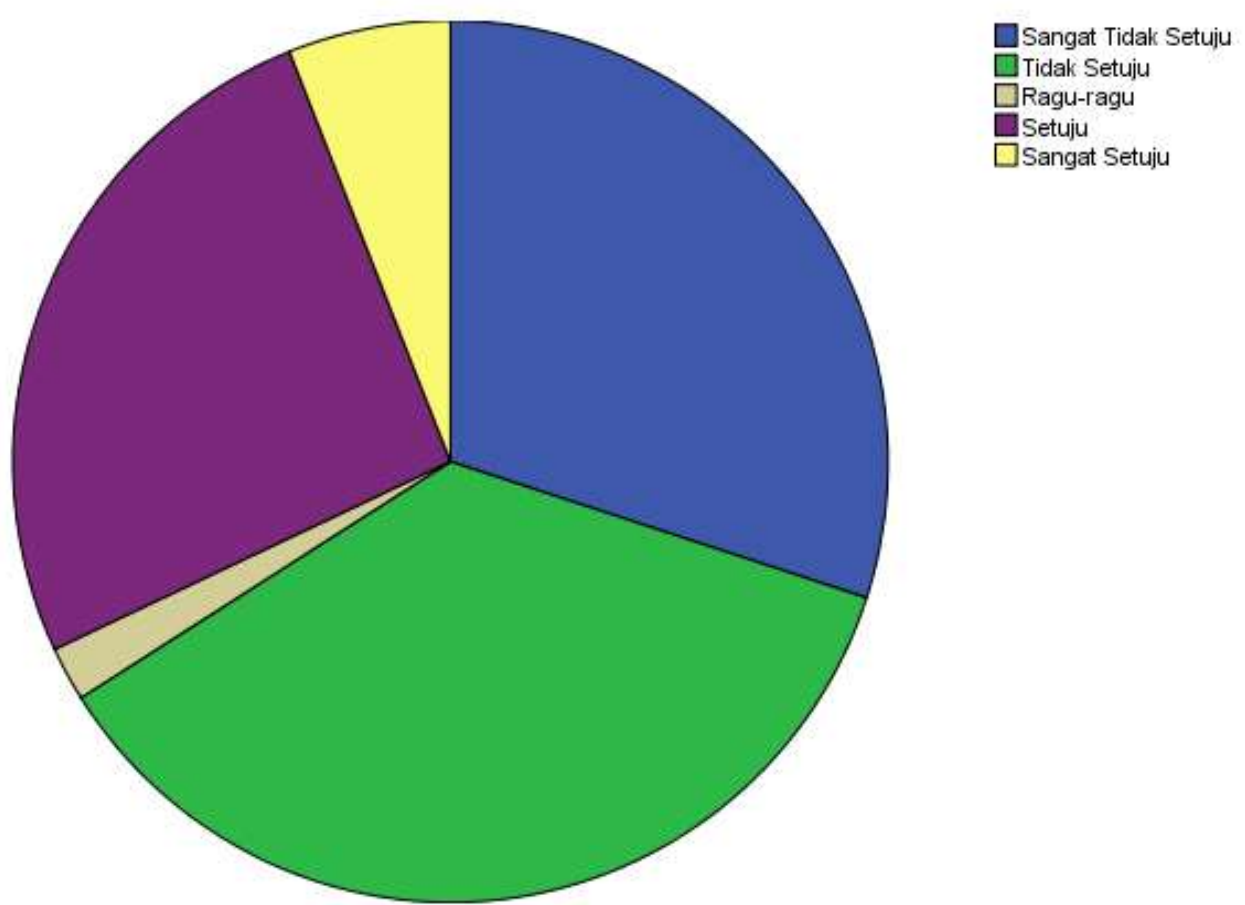

Gambar 5. Saya menyumpah dengan menyebutkan kata makian misalnya jahannam, antu kopek, jin betendang, puake, dsb

Puake, jin betendang, antu kopek adalah contoh nama-nama hantu yang dipercaya mendiami Pontianak oleh (sebagian) masyarakat Melayu Pontianak di Kalimantan Barat. Sebagian yang lain mempercayai bahwa jenis-jenis hantu ini sebaiknya tinggal di (neraka) jahannam. Itu sebabnya masyarakat Melayu Pontianak juga merujuk sifat-sifat buruk yang tidak baik dengan julukan tersebut. Berdasarkan tanggapan di atas, terlihat dan terbaca bahwa 30 responden sangat tidak setuju, 36 responden tidak setuju, dan 2 responden merasa ragu untuk menyatakan bahwa mereka menyumpah dengan menyebutkan kata makian misalnya jahannam, antu kopek, jin betendang, puake, dan sebagainya.. Sedangkan 26 responden setuju dan 6 responden sangat setuju menyatakan bahwa mereka menyumpah dengan menyebutkan kata makian misalnya jahannam, antu kopek, jin betendang, puake, dan sebagainya.

Secara persentase ini berarti bahwa 30 persen responden sangat tidak setuju, 36 persen responden tidak setuju, dan 2 persen responden merasa ragu untuk menyatakan bahwa mereka menyumpah dengan menyebutkan kata makian misalnya jahannam, antu kopek, jin betendang, puake, dan sebagainya. Sedangkan 26 persen responden setuju dan 6 persen responden sangat setuju menyatakan bahwa mereka menyumpah dengan menyebutkan kata makian misalnya jahannam, antu kopek, jin betendang, puake, dan sebagainya. 
Tuah Talino

Tahun XIII Volume 13 Nomor 2 Edisi 6 Desember 2019

ISSN 0216-079X E-ISSN 2685-3043

Balai Bahasa Kalimantan Barat

Lima pernyataan yang dijawab oleh responden ini sejatinya dapat menjadi jawaban akan gambaran mengenai ungkapan kemarahan dalam bentuk nyumpah dalam masyarakat Melayu Pontianak Kalimantan Barat ini. Selanjutnya jumlah respons tersebut akan diadisi dan disimpulkan secara menyeluruh.

\section{PENUTUP}

\section{Kesimpulan}

Adisi pernyataan responden berkenaan dengan ungkapan kemarahan dalam bentuk nyumpah dalam masyarakat Melayu Pontianak Kalimantan Barat dapat penulis simpulkan bahwa ungkapan kemarahan dalam bentuk nyumpah ini semakin tidak popular dalam masyarakat Melayu Pontianak Kalimantan Barat. Terdapat 20\% responden sangat tidak setuju dan $46 \%$ respons tidak setuju menyatakan bahwa mereka nyumpah untuk menunjukkan rasa marah karena kedekatan, kepedulian dan kasih sayang mereka pada orang yang dekat atau tidak dekat dengan mereka. Berdasarkan tanggapan responden, dapat disimpulkan bahwa sikap marah nyumpah semakin jarang dilakukan oleh responden (99 tanggapan setuju dan 21 tanggapan sangat setuju) karena hanya $20 \%$ reaksi setuju dan $4 \%$ reaksi sangat setuju dari responden untuk menunjukkan ungkapan kemarahannya dalam bentuk nyumpah disertai dengan ekspresi makian seperti jahannam, antu kopek, puake, dan jin betendang misalnya.

\section{Saran}

Hasil penelitian mengenai ungkapan kemarahan dalam masyarakat Melayu Pontianak Kalimantan Barat ini adalah bagaimana masyarakat Melayu Pontianak Kalimantan Barat mengungkapkanp kemarahannya dalam bentuk nyumpah. Hasil penelitian menunjukkan bahwa ungkapan kemarahan ini semakin tidak dipertahankan dalam masyarakat Melayu Pontianak Kalimantan Barat.

Selanjutnya terdapat beberapa saran dalam bentuk rekomendasi hal-hal yang dapat dilakukan terkait dengan penelitian ini, yaitu sebagai berikut.

1) Penelitian lebih lanjut mengenai ungkapan kemarahan dalam masyarakat Melayu Pontianak Kalimantan Barat ini direkomendasikan untuk dilanjutkan agar kita dapat mengetahui dan menganalisis lebih rinci mengenai mengapa ungkapan kemarahan dalam bentuk nyumpah dapat semakin hilang praktiknya dalam kehidupan masyarakat Melayu Pontianak Kalimantan Barat.

2) Penelitian lanjutan dengan menggunakan analisis variabel berbeda juga dapat menjadi fokus penelitian lanjutan karena hasil penelitian ini baru membahas ungkapan kemarahan dalam bentuk nyumpah yang secara umum terjadi diantara masyarakat Pontianak Kalimantan Barat. Pengerucutan analisis dengan menggunakan krostabulasi pada data ordinal responden, seperti: jenis kelamin, usia, status, lokasi tempat tinggal, bidang pekerjaan, bahasa pertama dan kedua, dan atau latar belakang keluarga juga dapat menjadi bahasan menarik yang lebih terpumpun pada penelitian lanjutan.

3) Penelitian korelasi juga bisa menjadi pilihan jika ingin membuat penelitian lanjutan mengenai relasi atau hubungan antara pengetahuan terhadap ungkapan 
kemarahan dengan sikap bagaimana mengungkapkan kemarahan tersebut dalam masyarakat Melayu Pontianak Kalimantan Barat.

Berbagai penelitian ini dapat menjadi rujukan pengetahuan yang sangat rinci dan akomodatif mengenai bagaimana suatu suku dalam hal ini suku atau masyarakat Melayu Pontianak Kalimantan Barat mengekspresikan atau mengungkapkan kemarahannya. Dasar pengetahuan ini sejatinya dapat mencegah konflik karena saling memahami tentang cara bersikap dan bertutur termasuk cara mengungkapkan kemarahan.

\section{DAFTAR PUSTAKA}

Kusnandar, Dadan dkk. (2019). Metode Statistika serta Aplikasinya dengan Minitab, Excel dan R. Pontianak: Untan Press.

Mahsun, M.S. (2005). Metode Penulisan Bahasa: Tahapan, Strategi, Metode dan Tehniknya. Jakarta: Rajawali Press.

--- (2007). Metode Penelitian Bahasa. Tahapan Strategi, Metode, dan Tekniknya. Jakarta: PT RajaGrafindo Persada.

Lubna, Syarifah. (2011). Beleter for Transfering Language and Cultural Moral Values to Young Malays at Pontianak, Kalimantan Barat dalam Timothy Mc Kinnon, dkk (ed): 251-255. International Seminar Proceeding: Language Maintenance and Shift. Semarang: Master's Program in Linguistics, Diponegoro University.

---. (2011). Beleter Pemertahanan Budaya Melayu dalam Ekspresi Kemarahan dalam Subyantoro, dkk (ed): 73-78. Prosiding Bahasa dan Sastra. Semarang: Universitas Negeri Semarang.

---. (2016). Ekspresi Kemarahan dalam Bahasa Melayu Pontianak Kalimantan Barat-Ekspression of Anger in Pontianak Malay West Kalimantan. Tuah Talino, 10(8), 60-68.

Shweder, Richard A. and LeVine, Robert A. (1984). Culture Theory Essay on Mind, Self, and Emotion. United States of America: Cambridge University Press.

Wierzbicka, Anna. (1992). Defining Emotion Concepts. Cognitive Science, 16.

--- (1991). Cross Cultural Pragmatics. The Semantic of Human Interaction. Mouten de Gruyter.

William, Angela A. (1998). Mother Tongue: Interviews with Musaemura B. Zimunya and Solomon Mutswairo. The Journal of African Travel-Writing, Number 4, April 1998.

\section{UCAPAN TERIMA KASIH}

Penulis mengucapkan terima kasih kepada Bapak Christanto Syam dan Ibu Sisilya Saman yang telah berkontribusi sebagai pembimbing tulisan yang merupakan bagian dari Tesis ini. 